\title{
뉴질랜드 원조정책 검토회의 결과
}

\section{I . 핵심내용}

$\mathrm{DAC}$ 는 뉴질랜드의 $\mathrm{GNI}$ 대비 $\mathrm{ODA}$ 비율이 DAC 회원국의 국가별 평균노력( $0.42 \%)$ 에 크게 미달한 $(0.23 \%)$ 점을 지적하면서 UN 목표치 $0.7 \%$ 달성 을 위하여 중기 원조목표 설정을 요청하였음.

ㅁ뉴질랜드가 대외원조의 효율성 제고를 위해 원조 전담기관 NZAID를 신설(2002년)하고 원조기관의 중점목표를 빈곤퇴치로 설정한 것을 긍정 평가하 였으나, 중점협력대상국 수(19개)가 많다고 지적하 면서 이를 축소하여 남태평양 국가들을 중점 지원 할 것을 권고함.

\section{II. 관찰}

ㅁ뉴질랜드는 ODA가 2.1억불(2004년)로써 DAC 회 원국중 원조규모가 제일 작지만 원조기관의 선진
화, $100 \%$ 무상원조 제공, 원조대상 및 원조분야의 집중 (태평양 도서국, 교육분야)을 통해 국제사회 로부터 모범적인 공여국 및 Good international citizen으로 인정받기를 모색하는 것으로 보이는 바, 우리에게 시사하는 바가 크다고 판단됨.

\section{III. 주요 논의사항}

\section{1. 원조기관 신설}

2000년 실시한 DAC의 원조정책 검토시 뉴질랜드 는 크게 두 가지 문제점이 지적된 바, 첫째는 다수 의 소규모 프로젝트의 실시 및 전략적 포커스의 부 재이고 둘째는 단기간 순환보직하는 외교관들이 개발협력을 담당함에 따라 Corporate capacities and professionalism이 형성되지 못한다는 것이 었음.

이에 따라 뉴질랜드 정부는 $\mathrm{ODA}$ 에 대한 전반적, 
객관적 평가를 실시하여 2002년 외교통상부 산하 에 반독자적인(Semi-autonomous body) 원조전 담기관(NZAID)을 신설한 바, DAC는 원조기관의 핵심목적이 빈곤퇴치로 설정되고 새로운 정책 및 우선순위(priorities)도입 등 매우 인상적인 성과를 보이고 있다고 높이 평가하였음.

NZAID가 빈곤퇴치에 중점을 두고 외교정책과 일 관성을 유지하면서 분리된 사업을 추진할 수 있다 는 점에서 외교통상부 산하의 반독자적 기관으로 설립한 것이 적절하였다고 평가하였음.

이러한 성과에도 불구하고 NZAID가 해결해야 할 과제로 예산부족, 원조의 분산(너무 많은 개도국에 대한 원조), field presence 강화 등이 지적되었음.

\section{ODA 증액문제}

ㅁ뉴질랜드 정부가 UN의 ODA 목표 $0.7 \%$ 를 장기적 목표로 하고 있으면서 지난 15 년간 ODA/GNI 비 율이 정체상태에 있고(2003년 0.23\%) 현재 ODA 증액을 위한 구체적인 계획이 없다는 문제점이 지 적됨.

이에 대해 뉴질랜드는 최근 ODA의 다년도 예산 제도가 도입되어 좀 더 예측가능한 장기지원계획 을 수립할 수 있게 되었고 작년 말 인도양 쓰나미 사태를 계기로 $\mathrm{ODA}$ 에 대한 국민들의 관심이 고조 되고 있으며 $\mathrm{ODA}$ 증액을 위한 주변환경이 개선되 고 있다고 함.

\section{3. 원조의 집중}

ㄴㄴㅈ질랜드는 19 개 중점협력대상국(태평양 11 개, 동
남아 7 개, 남아공) 외에도 20 여개국에 대하여 협 력사업을 하고 있으며 장학금사업, $\mathrm{NGO}$ 와의 공 동사업 포함시 수원국이 100 개국 이상에 달하고 있음. 이와 관련 $\mathrm{DAC}$ 는 원조기관(NZAID)의 부족 한 인원(본부 90 명, 해외 60명) 고려시 국별프로그 램 작성, 공여국간 조정 등을 위한 전략적 관리능 력, 거래비용(transaction cost) 등의 문제점을 지 적하면서 태평양에서 뉴질랜드 원조의 효율성을 감안, 이 지역에 대하여 집중할 것을 권고하였음. -뉴질랜드는 중점협력대상국을 6 개국으로 줄이 는 방안을 적극 검토중이라고 답변함.

ㅁ뉴질랜드는 전통적으로 교육분야 원조를 중시하 였고 2001년 국무회의에서 교육분야 원조를 개선 키로 하고 초등교육 예산을 $50 \%$ 이상 배정키로 결 정한 바, $\mathrm{DAC}$ 는 이를 환영하면서 동시에 기존의 다양한 장학금사업이 개발에 미치는 효과를 재검 토할 것을 권고함.

\section{4. 개발을 위한 정책일관성}

ㅁ뉴질랜드는 $\mathrm{DDA}$ 협상에서 개도국의 시장접근 개 선을 지지하고 있지만 개발을 위한 정책일관성을 명백하게 정부의 목표로 규정하고 있지 않은 점이 지적되었음.

이에 따라 $\mathrm{DAC}$ 는 개발을 위한 정책일관성을 분명 하게 지지하는 정치적 선언문의 채택을 권고하고 이를 위해 NZAID가 좀 더 적극적인 역할 (proactive role)을 할 것을 요청하였음. 


\section{5. 원조조화 및 원조일치}

ㅁ뉴질랜드와 호주 간의 협력을 통해 쿡아일랜드의 국가프로그램을 수립한 것이 원조조화의 모범사 례로 제시되었으며 솔로몬아일랜드의 교육사업 및 PNG 보건사업에서 뉴질랜드가 섹터별 접근방 식(sector-wide approach)를 추진하는데 주도적 역할을 한 것이 긍정적인 평가를 받았음.

ㅁ 그러나 DAC는 원조 현장에서 NZAID 사업과 뉴 질랜드 $\mathrm{NGO}$ 활동 간의 시너지 제고를 위한 협조 강화가 필요하며 수원국과의 정책대화 및 여타 공 여국과의 공조(coordination) 강화를 위해 $\mathrm{NZAID}$ 의 field presence의 강화가 필요하다는 권고를 하였음.

[자료:주오이시디 대표부] 